\title{
Effects of Fermentation on the Nutritional Quality of QPM and Soybean Blends for the Production of Weaning Food
}

\section{Buta $\mathrm{MB}^{1}$ and Emire $\mathrm{SA}^{2 *}$}

${ }^{1}$ Food Process Engineering Department, Addis Ababa Science and Technology University, Ethiopia

${ }^{2}$ Food, Beverage and Pharmaceutical Industry Development Institute, Ministry of Industry, Addis Ababa 3331, Ethiopia

\begin{abstract}
The purpose of this work was to study the effects of fermentation on quality protein maize (QPM) and soybean blends with respect to the nutritional quality including physico-chemical and functional properties; microbiological and sensory analyses, minerals and antinutrients composition. Quality protein maize-soybean blend flours were fermented for 24 and 48 hrs by natural and controlled fermentations. In contrary concentration of tannins and phytate were reduced significantly due to the fermentation process. Micronutrients increment in $(\mathrm{mg} / 100 \mathrm{~g})$ for $\mathrm{P}$, Fe and $\mathrm{Zn}$ was 32.57 to $61.9 ; 3.98$ to 7.20 and 2.61 to 4.21; respectively were revealed. Fermentation significantly $(p<0.05)$ decreased the antinutrients which resulted a significant increase in micronutrients. Microbiological result revealed significant reduction of undesirable coliform count and increment of LAB with increase in fermentation time. Sensory quality result showed that gruel prepared from the fermented blended flours at 24 hrs of fermentation time and $<250 \mu \mathrm{m}$ particle size was found acceptable. In line with the result of this study, natural and controlled fermentation uniformly reduced antinutrients composition and improved the nutritional quality of the weaning blends via increased energy and nutrient densities. Fermentation of cereal and legume blends is low-cost and safe technique to save life of children suffering from protein-energy malnutrition.
\end{abstract}

Keywords: Antinutrients; Fermentation; Micronutrient; Nutritional quality; Blends; Weaning food

\section{Introduction}

Fermentation is widely applied in the processing of cereals for the preparation of a wide variety of dishes in Africa and it contributes to the development of acceptable texture, flavour and improves the nutritional quality, digestibility and safety of foods [1]. Fermentation has also been identified to significantly improve the nutritional value (protein quality) of maize-based foods and as well reduce their antinutrients [2].

The high dependence on maize as a staple food in tropical Africa, coupled with the low nutritive value of the commodity has led to the investigation of simple traditional methods in the improvement of the chemical and functional qualities of maize-based foods [3]. The use of legumes such as soybean has been successfully used to increase the nutritional value of cereal foods. Soybean has high protein content and constitutes the natural protein supplements to staple diets. Protein quality is synergistically improved in cereal-legume blends because of the lysine, tryptophan and methionen contributed by the quality protein maize [4]. Soybean products are frequently incorporated into products used for the treatment or prevention of malnutrition. Enriching weaning foods with soy is a convenient, inexpensive, and highly effective way to upgrade the quality of traditional weaning foods and to provide the nutrition a growing child needs. Soy works together with grain proteins to achieve an overall increase in the value of the protein. Adding even small quantities of soy can greatly increase protein content and quality of weaning foods [5]. However, raw ingredients such as cereals and legumes that are used to prepare fermented foods contain significant amounts of antinutreints. These components may decrease the nutritional value of foods by interfering with mineral bioavailability and the digestibility of proteins and carbohydrates [6].

There is urgent need for provision of weaning foods rich in protein, low-cost and suitable for provision of infants' nutritional needs in order to reduce child malnutrition which is a major global health problem [7]. Blends with a cereal-legume ratio of 70: 30 have been introduced in many communities for use in the preparation of complementary foods with augmented protein quality. These foods should meet
World Health Organization estimated energy and nutrient needs from complementary foods [8]. The rationale of this study was to investigate the influence of fermentation on antinutrients composition, functional properties, physico-chemical and sensory characteristics of QPMbased soybean blended weaning foods in order to increase energy, nutrient densities and mineral bioavailability in a weaning gruel.

\section{Materials and Methods}

\section{Research materials collection and sample preparation}

Bako Hybrid Quality Protein Maize (BHQPY-545) and soybean (Afgat) varieties were collected from Bako and Hawassa Agricultural Research Centers; respectively. All experiments were performed at Addis Ababa Institute of Technology, Food Engineering laboratory, Ethiopian Health and Nutrition Research Institute and Kality Food Processing Share Company. Quality protein maize and soybean samples were prepared according to the method described [9].

\section{Blend formulation}

Formulations of high-protein-energy weaning blends were based on the material balance method, targeting $18 \%$ protein, $59 \%$ carbohydrates [10] and minimum energy value of $380 \mathrm{kcal}$ per $100 \mathrm{~g}$ dry matter, according to WFP requirement specifications for particularly the age group of 6 to 18 months. Therefore, the blend ratio of 82:18; QPM: soybean was formulated.

*Corresonding author: Emire SA, Food, Beverage and Pharmaceutical Industry Development Institute, Ministry of Industry, Addis, Ababa, Ethiopia, Tel: +2519336263; E-mail: shimelisemire@yahoo.com

Received September 14, 2015; Accepted October 01, 2015; Published October 07,2015

Citation: Buta MB, Emire SA (2015) Effects of Fermentation on the Nutritional Quality of QPM and Soybean Blends for the Production of Weaning Food. J Food Process Technol 6: 507. doi:10.4172/2157-7110.1000507

Copyright: $\odot 2015$ Buta MB, et al. This is an open-access article distributed unde the terms of the Creative Commons Attribution License, which permits unrestricted use, distribution, and reproduction in any medium, provided the original author and source are credited. 


\section{Natural and controlled fermentation process}

Fermentations (NF, CF) were performed using the methods described [11]. After fermentation the samples were dried and grounded and finally placed into plastic containers and stored at $4^{\circ} \mathrm{C}$.

\section{Proximate composition and determination of energy value}

After blend formulation both NF and CF fermentation process for 0,24 and 48 hours with particle size distribution of $<500 \mu \mathrm{m}$ and $<250 \mu \mathrm{m}$. The dried samples were analyzed for the parameters such as protein, crude fat and crude fiber using the method of AOAC and total carbohydrates were calculated by difference [12]

\section{Determination of nutrient and anti-nutrient concentration}

The micronutrients: iron, zinc and phosphorus were analyzed using atomic absorption spectoscopy. The antinutrients such as tannins and phytate were determined by the modified Vanillin assay [10].

\section{Determination of functional properties of blends}

Bulk density was determined by the method of Narayana [13]; dispersibility in water was determined by the method of Kulkarni [14]; water and oil absorption capacities were determined according to method described by Nwosu, Coffman [15,16]; respectively.

\section{Microbiological analysis}

Analyses of mold and yeast; aerobic plate count (APC), coliform count, fecal coliform count and E.coli were done using standard methods of ISO: 7954 [17]

\section{Sensory quality assessment}

The prepared weaning foods as gruel from famix provided from FAFA, QPM-Soybean blend flour and blend fermented for 24 and 48 hrs were evaluated by semi-trained panelists. The gruels were prepared by mixing about $10 \mathrm{~g}$ of blend flour dissolved in $200 \mathrm{ml}$ distilled water and cooked at $92^{\circ} \mathrm{C}$ for $15 \mathrm{~min}$. The panelists were asked to rank the gruel on the basis of appearance (color), odor, and taste using a nine point hedonic scale (where $1=$ dislike extremely and $9=$ like extremely). Overall acceptability of the samples was also rated on same scale with 9 $=$ extremely acceptable and $1=$ extremely unacceptable [18].

\section{Results and Discussion}

\section{Effect of fermentation on proximate composition and energy value of QPM-soybean blends}

Fermentation time significantly $(\mathrm{p}<0.05)$ affects protein content of blend flour (Table 1). As fermentation time increased from 0 to $24 \mathrm{~h}$ and $48 \mathrm{hrs}$, protein content of blends were $14.71 \%, 17.43 \%$ and $17.52 \%$; respectively. The protein content of blends before and after fermentation $(0,12$ and $24 \mathrm{hrs})$ was higher than the minimum protein requirement $(14 \%)$ of WFP specification for corn-soya blend and within the range (16.00\%-19.97\%) reported by Lalude [19].

As fermentation time increases the fat content of fermented blends increases from $8.42 \%$ to $10.9 \%$ with respect to the fermentation time of 0,24 and 48 hrs (Table 1). This is due to the removal of soluble carbohydrates during fermentation. According to the findings of Amankwah the fat content of formulation of weaning food from fermented maize, rice, soybean and fishmeal was $9.38 \%$ and $8.75 \%$ [20]. The experimental value is within the range with this value. The value of crude fat content of the blend before and after fermentation $(8.42 \%, 10.2 \%$, and $10.9 \%$ to $8.86 \%)$ is higher than the value of WFP specification for the minimum requirement of $6 \%$ fat of corn-soya blend. And it is comparable with the value of famix infant food $(\geq 7 \%)$. The fat content of current study is also within the range with the value (9.0\%) of Nutrend- commercially sold Nigerian weaning food.

The value of crude fiber after fermentation $(4.49 \%, 5.32 \%$ for particle size distribution of $<250 \mu \mathrm{m}$ and $5.19 \%, 4.67 \%$ for particle size distribution of $<500 \mu \mathrm{m}$ for natural fermentation) and $(5.91 \%$, $5.63 \%)$ for particle size distribution of $<250 \mu \mathrm{m}$ and $(6.88 \%, 5.96 \%)$ for particle size distribution of through $<500 \mu \mathrm{m}$ for controlled fermentation) at 24 and $48 \mathrm{~h}$ fermentation time respectively (Table $1)$. Fermentation time is significantly $(p<0.05)$ decreased the crude fiber contents of blend. According to high fiber contents of weaning foods may inhibit mineral absorption and reduce the digestibility of proteins in foods [21]. According to WHO specification the maximum requirement is $(5 \%)$. Therefore, the experimental values of the blends after fermentation are close to this value. Fermentation time had significantly $(p<0.05)$ decreasing effect on the total carbohydrates content of blend $(66.63 \%, 64.16 \%, 63.9 \%)$ and $(66.63 \%, 61.91 \%, 60.49 \%)$ for particle size distribution of $<250 \mu \mathrm{m}$ and $<500 \mu \mathrm{m}$ at 0,24 and $48 \mathrm{~h}$ fermentation time respectively as can be seen from the This is possibly due to the degradation of carbohydrates by microorganisms and the decreasing effect of fermentation upon the amount of Non-Digestible Carbohydrates (NDC) which are fibers (Table 1). All the experimental values of blend before and after fermentation are comparable with values $(67.21 \%$ and $63.32 \%)$ research findings by Mbata for fermented maize flour and Bambara groundnut-maize fortified flour [22]. It was reported that the total carbohydrate content of maize-soybean blend for the production of Ogi is $(61.76 \%)$; that is lower than the value of the current study [23].

In the case of controlled fermentation, the calorific values of the blends are decreased, even though there are some fluctuations in natural fermentation. This may be due to the value difference of the nutrients (protein, fat and carbohydrate) by the effect of fermentation process. The calorific value of the blend shown in the Table 1 , are in agreement with the researcher reported by Griffith [24]. The calorific value for weaning food revealed in the range of 395 to $509 \mathrm{kcal}$ which is in agreement with the value $(398.9 \mathrm{kcal})$ for "Nutrend" (Nestle, Nigeria-weaning diet) obtained commercially and the research finding reported by (441 kcal) [19]. The value is also within the range provided by WHO specification $(380 \mathrm{kcal})$ for the weaning food from corn-soya blend.

\section{Influence of fermentation process on antinutrients reduction of QPM-soybean blends}

During the preparation of many fermented foods, tannins are reduced before the fermentation step because of their presence in the seed coats of raw ingredients. In several fermented foods, the seed coat or testa is removed from the substrate before fermentation. Consequently, the antinutrients potential caused by the presence of tannins is of little concern [11]. Fermentation process further reduced tannins content of the blend (Table 2). Therefore, fermentation time significantly $(\mathrm{p}<0.05)$ affected tannins content of the blend. The phytate concentration present in raw materials and foods of plant origin are suggested to be a major factor responsible for lowering the availability of minerals and some proteins as reported [11]. Fermentation duration, type and particle size distribution greatly affects the composition of antinutients.

\section{Effect of reduction of antinutrients on micronutrients composition of blends}

The $\mathrm{P}, \mathrm{Fe}, \mathrm{Zn}$ and $\mathrm{Ca}$ concentrations of the blends before fermentation were $(32.57 \mathrm{mg} / 100 \mathrm{~g}, 3.98 \mathrm{mg} / 100 \mathrm{~g}, 2.61 \mathrm{mg} / 100 \mathrm{~g}$, 
Citation: Buta MB, Emire SA (2015) Effects of Fermentation on the Nutritional Quality of QPM and Soybean Blends for the Production of Weaning Food. J Food Process Technol 6: 507. doi:10.4172/2157-7110.1000507

Page 3 of 6

\begin{tabular}{|c|c|c|c|c|}
\hline $\begin{array}{l}\text { Fermentation type and particle size } \\
\text { distribution }\end{array}$ & Flour samples & Crude protein (\%) & $\begin{array}{l}\text { Crude fat } \\
\quad(\%)\end{array}$ & Crude fiber (\%) \\
\hline Before fermentation & Blend & $14.72^{g} \pm 0.03$ & $8.42^{\mathrm{ef}} \pm 0.01$ & $7.33^{\mathrm{ac}} \pm 0.02$ \\
\hline \multirow{2}{*}{$(<250 \mu \mathrm{m}), \mathrm{NF}$} & Blend24 & $17.43^{\mathrm{e}} \pm 0.02$ & $10.20^{b} \pm 0.14$ & $4.49^{h} \pm 0.08$ \\
\hline & Blend48 & $17.52^{\text {de }} \pm 0.01$ & $10.90^{9} \pm 0.28$ & $5.32^{\mathrm{fg}} \pm 0.01$ \\
\hline \multirow{2}{*}{$(<500 \mu \mathrm{m}), \mathrm{NF}$} & Blend24 & $17.57^{\mathrm{de}} \pm 0.06$ & $10.20^{\mathrm{b}} \pm 0.07$ & $5.19^{g} \pm 0.06$ \\
\hline & Blend48 & $17.85^{b} \pm 0.04$ & $10.80^{\text {de }} \pm 0.21$ & $4.67^{h} \pm 0.06$ \\
\hline \multirow{2}{*}{$(<250 \mu \mathrm{m}), \mathrm{CF}$} & Blend24 & $17.30^{f} \pm 0.21$ & $9.40^{c} \pm 0.14$ & $5.91^{\mathrm{e}} \pm 0.02$ \\
\hline & Blend48 & $17.67^{\mathrm{cd}} \pm 0.04$ & $8.50^{\text {ef }} \pm 0.35$ & $5.63^{e f} \pm 0.05$ \\
\hline \multirow{2}{*}{$(<500 \mu \mathrm{m}), \mathrm{CF}$} & Blend24 & $17.72^{\mathrm{bc}} \pm 0.01$ & $9.36^{c} \pm 0.06$ & $6.88^{b} \pm 0.04$ \\
\hline & Blend48 & $19.44^{k} \pm 0.05$ & $8.86^{d} \pm 0.02$ & $5.96^{e} \pm 0.04$ \\
\hline $\begin{array}{l}\text { Fermentation type and particle size } \\
\text { distribution }\end{array}$ & Flour samples & \multicolumn{2}{|c|}{ Carbohydrates (\%) } & Calorific value kcal/100g \\
\hline Before fermentation & Blend & \multicolumn{2}{|c|}{$66.63^{d} \pm 0.02$} & $400.81^{b}$ \\
\hline \multirow{2}{*}{$(<250 \mu \mathrm{m}), \mathrm{NF}$} & Blend24 & $66.90^{d} \pm 0.28$ & \multicolumn{2}{|c|}{$412.67^{f}$} \\
\hline & Blend48 & $65.01^{\mathrm{e}} \pm 0.08$ & \multicolumn{2}{|c|}{$412.25^{f}$} \\
\hline \multirow{2}{*}{$(<500 \mu \mathrm{m}), \mathrm{NF}$} & Blend24 & $66.74^{d} \pm 0.03$ & \multicolumn{2}{|c|}{$412.63^{f}$} \\
\hline & Blend48 & $67.97^{d} \pm 0.05$ & \multicolumn{2}{|c|}{$404.01^{\mathrm{h}}$} \\
\hline \multirow{2}{*}{$(<250 \mu \mathrm{m}), \mathrm{CF}$} & Blend24 & $64.16^{f} \pm 0.11$ & \multicolumn{2}{|c|}{$410.75^{d}$} \\
\hline & Blend48 & $63.90^{\mathrm{g}} \pm 0.42$ & \multicolumn{2}{|c|}{$387.06^{g}$} \\
\hline \multirow{2}{*}{$(<500 \mu \mathrm{m}), \mathrm{CF}$} & Blend24 & $61.91^{\mathrm{h}} \pm 0.36$ & \multicolumn{2}{|c|}{$387.54^{9}$} \\
\hline & Blend48 & $60.49^{i} \pm 0.06$ & & \\
\hline
\end{tabular}

All values are means $\pm S D$, Values in the same column with different superscripts for each type of analysis are significantly different $(P<0.05)$.

Where CF-Controlled fermentation and NF-Natural fermentation

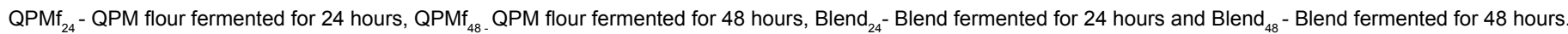
Table 1: Proximate chemical composition of blends

\begin{tabular}{|c|c|c|c|}
\hline $\begin{array}{l}\text { Fermentation type and particle size } \\
\text { distribution }\end{array}$ & $\begin{array}{l}\text { Flour } \\
\text { Samples }\end{array}$ & Tannins (mg/100g) & Phytate $(\mathrm{mg} / 100 \mathrm{~g})$ \\
\hline Before fermentation & Blend & $21.95^{\mathrm{c}} \pm 0.67$ & $249.2^{\mathrm{a}} \pm 0.14$ \\
\hline \multirow{2}{*}{$<250 \mu \mathrm{m}, \mathrm{NF}$} & Blend24 & $\mathrm{BDL}$ & $155.75^{d} \pm 0.53$ \\
\hline & Blend48 & $\mathrm{BDL}$ & $133.06^{e} \pm 0.04$ \\
\hline \multirow{2}{*}{$<500 \mu \mathrm{m}, \mathrm{NF}$} & Blend24 & $3.10^{c} \pm 0.21$ & $155.51^{d} \pm 0.36$ \\
\hline & Blend48 & BDL & $147.50^{f} \pm 0.35$ \\
\hline \multirow{2}{*}{$<250 \mu \mathrm{m}, \mathrm{CF}$} & Blend24 & $6.93^{e} \pm 0.02$ & $143.20^{9} \pm 0.14$ \\
\hline & Blend48 & $4.98^{d} \pm 0.06$ & $139.22^{i} \pm 0.16$ \\
\hline \multirow{2}{*}{$<500 \mu \mathrm{m}, \mathrm{CF}$} & Blend24 & $8.94^{f} \pm 0.04$ & $146.64^{h} \pm 0.45$ \\
\hline & Blend48 & $5.05^{d} \pm 0.11$ & $138.65^{i} \pm 0.46$ \\
\hline
\end{tabular}

Values in the same column with different superscripts for each type of analysis are significantly different $(P<0.05)$.

Where-BDL: Below detection limits

Table 2: Content of tannins and phytate of blends.

and $34.08 \mathrm{mg} / 100 \mathrm{~g}$ ) respectively. In the case of $\mathrm{NF}$, for particle size distribution of $<250 \mu \mathrm{m}$ and $<500 \mu \mathrm{m} \mathrm{P}$ of the blend is $(32.57 \mathrm{mg} / 100$ $\mathrm{g}, 61.90 \mathrm{mg} / 100 \mathrm{~g}, 61.20 \mathrm{~g} / 100 \mathrm{~g})$ and $(32.57 \mathrm{mg} / 100 \mathrm{~g}, 59.60 \mathrm{mg} / 100 \mathrm{~g}$, $55.30 \mathrm{mg} / 100 \mathrm{~g}$ ) during 0,24 , and $48 \mathrm{~h}$ fermentation time respectively. As can be seen from the Table $3, \mathrm{P}$ as fermentation increases from 0 to $24 \mathrm{~h}$ and 0 to $48 \mathrm{~h}$ increases too. The same is true for minerals: Fe; $\mathrm{Zn}$ and Ca that shows similarly increasing in values as fermentation time increased. This is due to the minerals of the grain that are not readily available for microorganisms as they are complexed with phytate, at $\mathrm{pH}$ values of $<5.5$ the endogenous grain phytase hydrolyses phytate and minerals are released from the complex [25].

Largely, fermentation time significantly $(\mathrm{p}<0.05)$ affect the mineral composition of the blend. The $\mathrm{Ca}, \mathrm{P}$, and Fe content are higher than the values $(22 \mathrm{mg} / 100 \mathrm{~g}, 26 \mathrm{mg} / 100 \mathrm{~g}, 1.0 \mathrm{mg} / 100 \mathrm{~g})$ reported by for Nutrend [19]. Values of iron and zinc are within the range of WHO standards ( $3.25 \mathrm{mg} / 100 \mathrm{~g}, 5 \mathrm{mg} / 100 \mathrm{~g}$ ) for the manufacture of corn soya blend for infants. The micronutrients values ( 17 to $25 \mathrm{mg} / 100 \mathrm{~g}$ for Ca; 7.19 to $10.98 \mathrm{mg} / 100 \mathrm{~g}$ for Fe and 1.78 to $2.01 \mathrm{mg} / 100 \mathrm{sg}$ for $\mathrm{Zn}$ ) are in agreement with the values for sorghum based weaning food [11].

\section{Effect of fermentation viscosity of QPM-soybean blends}

As indicated in Table 4, the viscosity of the blend is $\left(5.31 \times 10^{-3} \mathrm{~Pa} . \mathrm{s}\right)$ and the viscosity of blend gruel during fermentation of $24 \mathrm{~h}$ and 48 $\mathrm{h}$ is $\left(4.38 \times 10^{-3} \mathrm{~Pa} . \mathrm{s}, 4.21 \times 10^{-3} \mathrm{~Pa} . \mathrm{s}\right)$; respectively. From the results, fermentation time had significantly $(\mathrm{p}<0.05)$ decreasing effect on the viscosity of the blend. A prolonged time of starch gelatinization was observed while preparing gruels of fermented blend. This possibly is due to the degradation of starch granules during fermentation and this might cause for the reduction of starch swelling while cooking.

\section{Effect of fermentation on viscosity of QPM-soybean blends}

As indicated in Table 5 , the viscosity of the blend is $(5.31 \times 10$ $\left.{ }^{3} \mathrm{~Pa} . \mathrm{s}\right)$ and the viscosity of blend gruel during fermentation of $24 \mathrm{~h}$ and $48 \mathrm{~h}$ is $\left(4.38 \times 10^{-3} \mathrm{~Pa} . \mathrm{s}, 4.21 \times 10^{-3} \mathrm{~Pa}\right.$.s $)$ respectively. From the results, fermentation time had significantly $(\mathrm{p}<0.05)$ decreasing effect on the viscosity of the blend. A prolonged time of starch gelatinization was observed while preparing gruels of fermented blend. This possibly is due to the degradation of starch granules during fermentation so that 


\begin{tabular}{|c|c|c|c|c|c|}
\hline $\begin{array}{l}\text { Fermentation type and particle size } \\
\text { distribution }\end{array}$ & $\begin{array}{l}\text { Flour } \\
\text { Samples }\end{array}$ & $P(m g / 100 g)$ & $\mathrm{Fe}(\mathrm{mg} / 100 \mathrm{~g})$ & $\mathrm{Zn}(\mathrm{mg} / 100 \mathrm{~g})$ & $\mathrm{Ca}(\mathrm{mg} / 100 \mathrm{~g})$ \\
\hline Before fermentation & Blend & $32.57^{c} \pm 0.40$ & $3.98^{\text {ef }} \pm 0.06$ & $2.61^{f} \pm 0.08$ & $34.08^{\mathrm{c}} \pm 0.17$ \\
\hline \multirow{2}{*}{$<250 \mu \mathrm{m}, \mathrm{NF}$} & Blend24 & $61.90^{\mathrm{a}} \pm 0.64$ & $7.20^{\mathrm{a}} \pm 0.14$ & $4.21^{g} \pm 0.15$ & $24.91^{d} \pm 0.64$ \\
\hline & Blend48 & $61.20^{\text {ah }} \pm 0.14$ & $4.74^{c} \pm 0.03$ & $3.81^{\mathrm{cd}} \pm 0.08$ & $21.34^{e} \pm 0.24$ \\
\hline \multirow{2}{*}{$<500 \mu \mathrm{m}, \mathrm{NF}$} & Blend24 & $59.60^{d} \pm 0.42$ & $6.22^{d} \pm 0.16$ & $3.98^{g c} \pm 0.06$ & $24.92^{d} \pm 0.65$ \\
\hline & Blend48 & $55.30^{\mathrm{e}} \pm 0.21$ & $3.42^{b} \pm 0.03$ & $3.65^{d} \pm 0.06$ & $22.53^{f} \pm 0.37$ \\
\hline \multirow{2}{*}{$<250 \mu \mathrm{m}, \mathrm{CF}$} & Blend24 & $58.50^{f} \pm 0.35$ & $4.31^{\mathrm{e}} \pm 0.22$ & $2.89^{e} \pm 0.06$ & $65.02^{\mathrm{g}} \pm 0.01$ \\
\hline & Blend48 & $56.30^{g} \pm 0.21$ & $4.21^{\text {ef }} \pm 0.15$ & $2.81^{\mathrm{e}} \pm 0.04$ & $64.97^{9} \pm 0.02$ \\
\hline \multirow{2}{*}{$<500 \mu \mathrm{m}, \mathrm{CF}$} & Blend24 & $60.60^{h} \pm 0.42$ & $3.99^{\mathrm{ef}} \pm 0.06$ & $2.84^{e} \pm 0.03$ & $65.42^{g} \pm 0.30$ \\
\hline & Blend48 & $54.30^{i} \pm 0.21$ & $3.88^{f} \pm 0.07$ & $2.71^{\text {ef }} \pm 0.04$ & $64.77^{g} \pm 0.54$ \\
\hline
\end{tabular}

Values in the same column with different superscripts for each type of analysis are significantly different $(P<0.05)$.

Table 3: Micronutrient composition of blends.

\begin{tabular}{|c|c|}
\hline Blend with respective fermentation time & Viscosity (Pa.s) \\
\hline Blend & $5.31 \times 10^{-3 b} \pm 0.22$ \\
\hline Blend24 & $4.38 \times 10^{-3 e} \pm 0.26$ \\
\hline Blend48 & $4.21 \times 10^{-3 e} \pm 0.15$ \\
\hline
\end{tabular}

Values in the same column with different superscripts for each type of analysis are significantly different $(P<0.05)$.

Table 4: Viscosity of gruel from blends at a temperature of $50^{\circ} \mathrm{C}$.

cause for the reduction of starch swelling while cooking. According to Plahar in terms of starch stability, fortification with soy flour is a cause for strengthening of the starch granules [26].

\section{Impact of fermentation on functional properties of QPM- soybean blends}

Bulk density and dispercebility: As fermentation time increase from 0 to 24 and $48 \mathrm{~h}$, the bulk density significantly decreases for QPM-Soybean blends. The bulk density of QPMf before fermentation is $(0.84$ and 0.92$)$ and after fermentation of 24 and $48 \mathrm{~h}$ is $(0.62,0.59$ and $0.63,0.6)$ for particle size distribution between $<250$ and $<500$ $\mu \mathrm{m}$; respectively. The bulk density of QPMf before fermentation is significantly $(\mathrm{p}<0.05)$ higher than that of after fermentation. The values $(0.66$ and 0.61$)$ of the current research finding is in agreement with that of reported Lalude [19], of a weaning food prepared from sorghum based and Nutrend. Similarly, the values are comparable with value (0.68) reported by Mesfin [27]. As fermentation time increased the value of dispercebility significantly $(\mathrm{p}<0.05)$ increased from $0.65 \%$, $69 \%$ to $66 \%, 67 \%$ and $65 \%, 69 \%$ for fermentation time of 24 and $48 \mathrm{~h}$ and particle size distribution of $<250$ and $<500 \mu \mathrm{m}$; respectively. The values of both bulk density and dispersability of QPMf and blend are higher than the values $(0.55 \mathrm{gm} / \mathrm{ml}$ and $32.93 \%)$ reported by Ahima respectively [28].

Water and oil absorption: As indicated in Table 5, water absorption of both QPMf and blend is significantly $(\mathrm{p}<0.05)$ decreased when fermentation time increased from 0 to $24 \mathrm{~h}$ and from 0 to $48 \mathrm{~h}$. Ahima reported that the water absorption of flour from commercially sold floury maize and Maize-soy flour blend is (194.65\% and $172.98 \%$ respectively) [28]. This result indicated that the water absorption of QPMf and blend is lower than that of the researches findings. In the current study the unfermented and fermented blends found to contain comparable amount of water absorption with (134\%) that is reported by Emmanuel, cowpea-fortified nixtamalized food. Oil absorption capacity of QPMf $(1.4 \mathrm{ml}, 2.3 \mathrm{ml})$ is higher than of blend $(1.2 \mathrm{ml}, 1.7 \mathrm{ml})$ with particle size distribution of $<250 \mu \mathrm{m}$ and $<500$ $\mu \mathrm{m}$. Similarly, QPMf fermented for $24 \mathrm{hrs}$ and $48 \mathrm{hrs}(4.2 \mathrm{ml}, 5.2 \mathrm{ml}$ and $4.8 \mathrm{ml}, 5.0 \mathrm{ml}$ ) is significantly higher than that of fermented blend $(2.2 \mathrm{ml}, 3.0 \mathrm{ml}$ and $1.9 \mathrm{ml}, 2.8 \mathrm{ml})$ for particle size of $<250 \mu \mathrm{m}$ and
$<500 \mu \mathrm{m}$ respectively. These results indicated that blending QPMf with soybean flour significantly $(\mathrm{p}<0.05)$ decreased the oil absorption of the blend. Therefore, blend ratio and fermentation time has significantly $(p<0.05)$ a decreasing effect on the oil absorption. The values obtained from current study are higher than that of $(1.22 \mathrm{ml}-2.23 \mathrm{ml})$ reported by Mensah of extrusion cooking of full-fat soy flour [29]. Similarly, oil absorption of both fermented QPMf and blend are higher than the value $(1.82 \mathrm{ml}, 1.44 \mathrm{ml})$ for different varieties reported by Assefa of improved varieties of soybean in Ethiopia [30].

\section{Sensory quality attributes of value added products}

The average results of taste evaluation by the panelist for the control, fermented for $24 \mathrm{~h}$, unfermented blend and fermented for $48 \mathrm{~h}$ were 8.9 (like extremely); 7.8 (like very much); 7.2 (like moderately) and 5.8 (like slightly) respectively. The overall acceptability of gruel fermented for $24 \mathrm{~h}$ with the average value of 8.5 is not significantly different ( $p>0.05$ ) compared with that of the control. The result of the others ranged 5.9 to 7.1. This might be due to all the products are evaluated without flavoring agents. Similar results on weaning and commentary food products were report by Abbey, Beruk [31,32] (Table 6).

\section{Microbiological quality of blends}

In Table 7 mould count, yeast count, Aerobic Bacteria plate Count (APC), coliform count and others are shown. The result indicated that as fermentation time increased, the undesirable microorganism, mould count, decreased significantly for both type of fermentation. The molds isolated in the current study are commonly present as contaminants and do not appear to play any significant important role in the fermentation process. This shows clearly that the importance of fermentation in the aspect of food preservation.

At $0 \mathrm{hr}$ fermentation time, the yeast count was found to be $<1 \times 10^{1}$ $\mathrm{cfu} / \mathrm{g}$, which is considered to be no yeast colonies in the count, but during 24 and $48 \mathrm{~h}$ fermentation, the values were increased upon both Natural and Controlled Fermentation. This shows that fermentation time significantly $(\mathrm{p}<0.05)$ affect the yeast count. The coliform count at the start of fermentation was found to be $4.3 \times 10^{2} \mathrm{cfu} / \mathrm{g}$ and upon increasing fermentation time, 24 and $48 \mathrm{~h}$ the count was decreased to $3.1 \times 10^{2} \mathrm{cfu} / \mathrm{g}$ and $3.2 \times 10^{2} \mathrm{cfu} / \mathrm{g}$ in the case of NF and almost eliminated $\left(<1 \times 10^{1} \mathrm{cfu} / \mathrm{g}\right)$ in the case of CF. The expected decrease or elimination of coliform is in agreement with the value $(2.85 \mathrm{cfu} / \mathrm{g}, 0 \mathrm{cfu} / \mathrm{g}, 0 \mathrm{cfu} / \mathrm{g})$ for 0,24 and 48 hrs fermentation time reported by Mbata of fermented maize flour fortified with bambara groundnut [22]. The aerobic bacteria plate count, (APC) as shown in the Table 7 is $1.8 \times 10^{2} \mathrm{cfu} / \mathrm{g}$ at $0 \mathrm{~h}$ fermentation time and $\left(2.6 \times 10^{3} \mathrm{cfu} / \mathrm{g}, 2.4 \times 10^{3} \mathrm{cfu} / \mathrm{g}\right)$ in the case of NF and $\left(6.7 \times 10^{3} \mathrm{cfu} / \mathrm{g}, 5.7 \times 10^{3} \mathrm{cfu} / \mathrm{g}\right)$ for CF during 24 and $48 \mathrm{hrs}$ fermentation time; respectively. Aerobic plate counts taken at $24 \mathrm{~h}$ 


\begin{tabular}{|c|c|c|c|c|}
\hline $\begin{array}{l}\text { Types of } \\
\text { flour }\end{array}$ & $\begin{array}{l}\text { Bulk density } \\
(\mathrm{g} / \mathrm{ml})\end{array}$ & $\begin{array}{l}\text { Dispersibility } \\
(\%)\end{array}$ & $\begin{array}{l}\text { Water } \\
\text { absorption (\%) }\end{array}$ & $\begin{array}{l}\text { Oil absorption } \\
\text { (ml/g of sample) }\end{array}$ \\
\hline QPMF $_{<250}$ & $0.84^{\mathrm{a}} \pm 0.01$ & $65^{a} \pm 0.71$ & $139.09^{a} \pm 0.06$ & $1.4^{\text {af }} \pm 0.07$ \\
\hline QPMF $_{<500}$ & $0.92^{b} \pm 0.02$ & $69^{c} \pm 0.35$ & $136.27^{b} \pm 0.19$ & $2.3^{b} \pm 0.11$ \\
\hline QPMF $_{<250,24}$ & $0.62^{\mathrm{efg}} \pm 0.01$ & $66^{a} \pm 1.41$ & $129.23^{c} \pm 0.16$ & $4.7^{c} \pm 0.21$ \\
\hline QPMF $_{<25}$ & $0.59^{f g} \pm 0.02$ & $67^{\mathrm{ab}} \pm 2.12$ & $137.17^{d} \pm 0.12$ & $5.2^{\mathrm{d}} \pm 0.12$ \\
\hline QPMF $_{<500,24}$ & $0.63^{\text {efg }} \pm 0.01$ & $65^{\mathrm{ab}} \pm 0.71$ & $139.73^{a} \pm 0.52$ & $4.8^{\mathrm{ce}} \pm 0.14$ \\
\hline QPMF $_{<500,48}$ & $0.60^{9} \pm 0.02$ & $69^{c} \pm 1.41$ & $144.80^{\mathrm{e}} \pm 0.57$ & $5.0^{\mathrm{de}} \pm 0.07$ \\
\hline Blend $_{<250}$ & $0.77^{c} \pm 0.01$ & $57^{e} \pm 1.06$ & $142.00^{f} \pm 0.35$ & $1.2^{f} \pm 0.11$ \\
\hline Blend $_{<500}$ & $0.79^{c} \pm 0.03$ & $64^{a} \pm 0.35$ & $136.33^{\mathrm{b}} \pm 0.23$ & $1.7^{\mathrm{ag}} \pm 0.12$ \\
\hline Blend $_{<250,24}$ & $0.74^{d} \pm 0.01$ & $67^{b c} \pm 1.41$ & $140.37^{9} \pm 0.26$ & $2.2^{\mathrm{bh}} \pm 0.14$ \\
\hline Blend $_{<2:}$ & $0.67^{e} \pm 0.02$ & $60^{d} \pm 0.71$ & $146.00^{h} \pm 0.21$ & $3.0^{i} \pm 0.13$ \\
\hline Blend $_{<50}$ & $0.75^{\mathrm{cd}} \pm 0.01$ & $66^{\mathrm{ab}} \pm 0.02$ & $126.13^{i} \pm 0.09$ & $1.9^{g h} \pm 0.07$ \\
\hline Blend $_{<500,48}$ & $0.65^{\mathrm{ef}} \pm 0.03$ & $65^{\mathrm{a}} \pm 2.12$ & $132.83^{j} \pm 0.59$ & $2.8^{i} \pm 0.21$ \\
\hline
\end{tabular}

Values in the same column with different superscripts for each type of analysis are significantly different $(P<0.05)$.

Table 5: Bulk density, dispensability, water and oil absorption of blends.

\begin{tabular}{|l|l|l|l|l|}
\hline Sample code & Appearance & Odor & Taste & $\begin{array}{l}\text { Overall } \\
\text { acceptability }\end{array}$ \\
\hline Control (Famix) & $8.30^{\mathrm{a}} \pm 0.65$ & $8.80^{\mathrm{a}} \pm 0.24$ & $8.90^{\mathrm{a}} \pm 0.23$ & $8.90^{\mathrm{a}} \pm 0.34$ \\
\hline Blend $_{<500}$ & $6.00^{\mathrm{b}} \pm 1.73$ & $6.67^{\mathrm{b}} \pm 1.15$ & $7.30^{\mathrm{b}} \pm 0.58$ & $7.00^{\mathrm{b}} \pm 0.00$ \\
\hline Blend $_{<250}$ & $6.40^{\mathrm{b}} \pm 1.20$ & $6.69^{\mathrm{b}} \pm 0.84$ & $7.10^{\mathrm{b}} \pm 0.51$ & $7.20^{\mathrm{b}} \pm 0.57$ \\
\hline Blend $_{24<500}$ & $7.70^{\mathrm{cd}} \pm 0.00$ & $7.33^{\mathrm{c}} \pm 0.58$ & $7.70^{\mathrm{c}} \pm 0.56$ & $8.30^{\mathrm{c}} \pm 0.43$ \\
\hline Blend $_{48<500}$ & $7.00^{\mathrm{e}} \pm 0.58$ & $5.70^{\mathrm{d}} \pm 1.13$ & $5.70^{\mathrm{d}} \pm 0.60$ & $6.00^{\mathrm{d}} \pm 0.26$ \\
\hline Blend $_{24<250}$ & $7.80^{\mathrm{ac}} \pm 0.44$ & $7.54^{\mathrm{e}} \pm 0.78$ & $8.10^{\mathrm{e}} \pm 0.47$ & $8.50^{\mathrm{ac}} \pm 0.62$ \\
\hline Blend $_{48<250}$ & $7.50^{\mathrm{d}} \pm 0.39$ & $5.90^{\mathrm{d}} \pm 0.95$ & $6.00^{\mathrm{d}} \pm 0.86$ & $5.80^{\mathrm{d}} \pm 0.18$ \\
\hline
\end{tabular}

All values in the same column with different superscripts for each type of analysis are significantly different $(P<0.05)$.

Table 6: Sensory quality evaluation of weaning food.

\begin{tabular}{|l|l|l|l|l|l|}
\hline \multirow{2}{*}{ Isolated microorganisms } & \multicolumn{5}{|c|}{ Microbial count load (cfu/g) of blend samples } \\
\cline { 2 - 6 } & 0 & $24, \mathrm{NF}$ & $48, \mathrm{NF}$ & $24, \mathrm{CF}$ & $48, \mathrm{CF}$ \\
\hline Mold count at $\mathbf{2 5}^{\circ} \mathbf{C} / 5-7$ days & $2.1 \times 10^{4}$ & $4 \times 10^{2}$ & $3.2 \times 10^{2}$ & $5 \times 10^{2}$ & $4 \times 10^{2}$ \\
\hline Yeast count at $22^{\circ} \mathrm{C} / 5-7$ days & $\mathrm{Nil}$ & $2.9 \times 10^{2}$ & $3.2 \times 10^{2}$ & $2.0 \times 10^{2}$ & $3.5 \times 10^{2}$ \\
\hline APC at $30^{\circ} \mathrm{C} / 72 \mathrm{~h}$ & $1.8 \times 10^{2}$ & $2.6 \times 10^{3}$ & $2.4 \times 10^{3}$ & $6.7 \times 10^{3}$ & $5.7 \times 10^{3}$ \\
\hline Coliform count & $4.3 \times 10^{2}$ & $3.1 \times 10^{2}$ & $3.2 \times 10^{2}$ & $\mathrm{Nil}$ & $\mathrm{Nil}$ \\
\hline Fecal coliform count & $\mathrm{Nil}$ & $\mathrm{Nil}$ & $\mathrm{Nil}$ & $\mathrm{Nil}$ & $\mathrm{Nil}$ \\
\hline E.coli count & $\mathrm{Nil}$ & $\mathrm{Nil}$ & $\mathrm{Nil}$ & $\mathrm{Nil}$ & $\mathrm{Nil}$ \\
\hline S.coccus spp & $\mathrm{Nil}$ & $\mathrm{Nil}$ & $\mathrm{Nil}$ & $\mathrm{Nil}$ & $\mathrm{Nil}$ \\
\hline
\end{tabular}

Values in the same column with different superscripts for each type of analysis are significantly different at $\mathrm{P}<0.05$.

Table 7: Microbiological quality of blends at different fermentation time for NF and CF.

intervals of fermentation indicated that the increased growth of yeasts and lactic acid bacteria gradually throughout fermentation while the decrease in numbers of molds and coliforms.

\section{Conclusions}

In this research, it was observed that fermentation process significantly changed the nutritional value of the weaning blends by reducing antinutrients. The maximum reduction of phytate due to fermentation effect can lead to the increment of the bioavailability of micronutrients. Subsequently, 47.4\% (P), 47.9\% (Ca), 44.7\% (Fe) and $38 \%(\mathrm{Zn})$ increment was observed. The fermentation process affected the energy value and nutrient densities of the weaning blends. Gruels prepared from fermented blend flours were less viscous and the dietary bulkiness nature was improved. The microbial load of blend samples at different fermentation time for NF and CF found acceptable; and the sensory quality evaluation of the prepared gruel was acceptable by panelists. An infant food of higher energy and nutrient density formulated and prepared from a formulation of $82 \%$ quality protein maize and $18 \%$ soybean had the strongest impact on nutritional quality; and should be viewed as an option in the development of infant weaning foods in order to reduce child malnutrition problem in the Ethiopian context.

Accordingly, the use of cereal based legume blends with augmented protein quality could help rural communities predominantly to make better use of their available resources; and the same time can improve nutrient density and fulfill the minimum daily requirements for energy, protein and micronutrients. Promotional efforts should be made to transfer technique of this high-protein-energy weaning blends formulation and processing technology to food manufacturing industries and household women in order to diminish child mortality in Sub-Saharan African Countries.

\section{References}

1. Campbell PG (1994) Fermented foods - a world perspective. Food Res Int 27 : 253-268.

2. Reddy NR, Pierson MD, Salunkhe DK (1986) Legume-based Fermented Foods. In: Reddy NR, Pierson MD, Salunkhe DK (Eds) CRC Press, Boca Raton, Florida.

3. Bressani R, Benavides V, Acevedo E, Ortiz MA (1990) Changes in selected nutrient content and in protein quality of common and quality protein maize during tortilla preparation. Cereal Chem 67: 515-518.

4. Emmanuel OA, Sefa-Dedeh S, Agnes SB, Sakyi-Dawson E, Justice A (2007) Influence of spontaneous fermentation on some quality characteristics of maize-based cowpea-fortified nixtamalized foods 7 .

5. Louis St (2006) Weaning Foods: Characteristics, Guidelines, and the Role of Soy foods. WISHH World Initiative for Soy in Human Health.

6. Reddy NR, Pierson MD (1994) Reduction in antinutritional and toxic components in plant foods by fermentation. Food Res Inter 27: 281-290.

7. Kim F, Camilla H, Nanna R, Pernille K, Maria S, et al. (2009) Choice of foods and ingredients for moderately malnourished children 6 months to 5 years of age. Food Nutr Bull 30: 343-403.

8. Ejigui J, Savoie L, Marin J, Desrosiers T (2007) Improvement of the nutritiona quality of a traditional complementary porridge made of fermented yellow maize (Zea mays): Effect of maize-legume combinations and traditional processing methods. Food Nutr Bull 28: 23-34.

9. Bryce JB, Shibuya K, Black RE (2005) WHO six reports on the World Health Situation, Part I. Global analysis, Geneva. 365: 1147- 1152

10. Butler LG, Price ML, Brotherton JE (1982) Vanillin assay for Proanthocyanidins (Condensed Tannins): Modification of the Solvent for Estimation of the Degree of Polymerization. J Agric Food Chem 30: 1087-1089.

11. Emire SA, Rakshit SK (2005) Proximate composition and physico-chemical properties of improved dry bean (Phaseolus vulgaris L.) varieties grown in Ethiopia. LWT 38: 331-338.

12. AOAC (2000) Association of Official Analytical Chemists. (17thedn) AOAC International. Washington, DC, USA.

13. Narayana K, Narasinga Rao MS (1984) Effect of partial proteolysis on the functional properties of winged pea flour. J Food Sci 49: 944-947.

14. Kulkarni KD, Kulkarni DN, Ingle UM (1991) Sorghum malt based weaning food formulations, preparations, functional properties and nutritive values. Food Nut Bull 13: 322-329.

15. Nwosu JN, Onuegbu NC, Kabuo NO, Okeke MO (2010) The effects of steeping with chemicals (Aluma and Tona) on the proximate and functional properties of pigeon pea (Cajanus cajan) flour. Pak J Nutr 9: 762-768.

16. Coffman CW, Gracia VV (1977) Functional properties of amino acid content of protein isolate from mung bean flour. J Food Technol 12: 473-484.

17. ISO: 7954 (1987) Microbiology: general guidance for enumeration of yeasts and moulds - Colony count technique at $25^{\circ} \mathrm{C}$ 
Citation: Buta MB, Emire SA (2015) Effects of Fermentation on the Nutritional Quality of QPM and Soybean Blends for the Production of Weaning Food. J Food Process Technol 6: 507. doi:10.4172/2157-7110.1000507

18. Inyang CU, Idoko CA (2006) Assessment of the quality of ogi made from malted millet. Afri J Biotech 5: 2334-2337.

19. Lalude LO, Fashakin JB (2006) Development and nutritional assessment of a weaning food from sorghum and oil-seeds. Pak J Nutr 5: 257-260.

20. Amankwah EA, Barimah J, Acheampong R, Addai LO, Nnaji CO (2009) Effect of fermentation and malting on the viscosity of Maize-Soyabean weaning blends. Pak J Nutr 8: 1671-1675.

21. Amuna $P$, Zotor F, Sumar S, Chinyanga $Y T$ (2000) The role of traditional cereal/legume/fruit-based multi-mixes in weaning in developing countries. J Nutr Food Sci 30: 116-122.

22. Mbata TI, Ikenebomeh MJ, Alaneme JC (2009) Studies on the microbiological, nutrient composition and antinutritional contents of fermented maize flour fortified with bambara groundnut (Vigna subterranean L). Afri J Food Sci 3: 165-171.

23. Bolaji OA, Olubunmi OA, Samuel AG (2010) Quality assessment of selected cereal-soybean mixtures in ogi production. New York Science Journal 3: 17-26.

24. Griffith LD, Castell-Perez ME, Griffith ME (1998) Effects of blend and processing method on the nutritional quality of weaning foods made from select cereals and legumes. American Association of Cereal Chem Inc 75: 105-112.

25. Hammes PW, Brandt JM, Francis LF, Rosenheim SH, Vogelmann AS (2005) Microbial ecology of cereal fermentations trends. Food Sci Technol 16: 4-11.
26. Plahar WA, Nti CA, Annan NT (1997) Effect of soy fortification method on the fermentation characteristics and nutritional quality of fermented maize meal Plant Foods Hum Nutr 51: 365-380.

27. Mesfin W, Shimelis AE (2013) Effect of soybean/cassava flour blend on the proximate composition of Ethiopian traditional bread prepared from quality protein maize. Afri J Food, Agric Nutri Develop 13: 7985-8003.

28. Ahima KJ (2005) Formulation of weaning food using composite of maize groundnut and soybean and assessing its nutritional effect using animal model.

29. Mensah P, Drasar BS, Harrison TJ, Tomkins AM (1991) Fermented Cereal Gruels: Towards A Solution of The Weanling's Dilemma. Food Nutr Bull 13: 50-57.

30. Yimer A, Admassu S (2008) Effect of processing on some antinutritional factors of improved soya bean (Glycine max) varieties grown in Ethiopia. Addis Ababa University, Addis Ababa.

31. Abbey BW, Nkanga UE (1988) Production of high quality weaning products from Maize-Cowpea-Crayfish mixtures. Nutr Rept Int 37:952-957.

32. Beruk BD, Kebede A, Esayas K (2015) Effect of blending ratio and processing technique on physicochemical composition, functional properties and sensory acceptability of quality protein maize (QPM) based complementary food. Inter J Food Sci Nutri Eng 5: 121-129. 